Halina Pawlak

Uniwersytet Jagielloński

\title{
Ocena wykorzystania środków finansowych w ramach programu „Różnicowanie w kierunku dzialalności nierolniczej”
}

Tereny wiejskie w Polsce charakteryzują się wzrostem zróżnicowania zarówno pod względem gospodarczym, jak i społecznym. Następuje ciągła przemiana tych obszarów, zmienia się też ich funkcja. Zdominowanie przez rolnictwo ustępuje wzrostowi wielofunkcyjności terenów wiejskich. Zwraca się coraz większą uwagę na potrzebę rozwoju pozarolniczych funkcji gospodarczych (Bański 2004).

Wpływ na rozwój alternatywnych źródeł dochodu na wsi mają czynniki społeczne, ekonomiczne i techniczne. Wśród ekonomicznych szczególną rolę odgrywa pomoc finansowa ze środków Unii Europejskiej (Bański 2004). W ostatnich latach wzrasta w Polsce liczba gospodarstw rolniczych, które prowadzą dodatkowo działalność pozarolniczą. W 2005 r. 57\% rodzin wiejskich utrzymywało się z pracy poza gospodarstwami rolniczymi (Błąd 2006). Przystąpienie do Unii Europejskiej i pozyskanie środków wspierających tereny wiejskie postrzegane jest jako szansa na rozwiązanie głównych problemów polskiego rolnictwa: przeludnienia agrarnego, rozdrobnienia gospodarstw czy braku kapitału (Fałkowski 2005). Pobudzanie działalności gospodarczej na obszarach wiejskich będzie pośrednio wpływać na poprawę konkurencyjności i ukierunkowania rynkowego produkcji, ale przede wszystkim może wpłynąć na poprawę jakości życia na wsi (Babuchowska 2009).

Po przystąpieniu Polski do UE tereny wiejskie zostały objęte dwoma programami, w znacznym stopniu finansowanymi ze środków Unii Europejskiej. W latach 2004-2006 realizowany był Sektorowy Program Operacyjny „Restrukturyzacja i modernizacja sektora żywnościowego oraz rozwój obszarów wiejskich” (SPO 2004-2006). Natomiast w latach 2007-2013 był realizowany (i nadal jest) Program Rozwoju Obszarów Wiejskich (PROW).

\section{Wsparcie finansowe dla działalności pozarolniczych na terenach wiejskich - charakterystyka wybranych programów}

Sektorowy Program Operacyjny „Restrukturyzacja i modernizacja sektora żywnościowego oraz rozwój obszarów wiejskich" był realizowany ze środków Unii Europejskiej pochodzących z Europejskiego Funduszu Orientacji i Gwarancji Rolnej (EFOiGR) oraz z krajowych środków publicznych. Program miał na celu poprawę konkurencyjności oraz trwały i zrównoważony rozwój sektora rolnego, a także wsparcie przemysłu przetwórczego i wielofunkcyjnego rozwoju obszarów wiejskich. Powyższe cele realizowano w ramach trzech priorytetów. Priorytet 
drugi to „Zrównoważony rozwój obszarów wiejskich”, a w nim działanie 2.4 „Różnicowanie działalności rolniczej i zbliżonej do rolnictwa w celu zapewnienia różnorodności działań lub alternatywnych źródeł dochodu" (Rdr SPO). Celem działania Rdr SPO było sprzyjanie tworzeniu alternatywnych źródeł dochodów, promowanie pozytywnego wizerunku wsi i rolnictwa w społeczeństwie, sprzyjanie zachowaniu zasobów przyrodniczych obszarów wiejskich, ułatwianie dostępu rolnikom oraz pozostałym mieszkańcom wsi do usług oraz przyczynianie się do zwiększania opłacalności produkcji i usług w gospodarstwie rolnym (SPO 2005). Podjęcie lub rozwój dodatkowej działalności miało na celu wykorzystanie istniejących zasobów gospodarstwa i regionu w celu stworzenia warunków do rozwoju wielofunkcyjnych i trwałych ekonomicznie gospodarstw rolnych (SPO 2005).

W latach 2007-2013 w ramach II filaru Wspólnej Polityki Rolnej wcielany jest w życie Program Rozwoju Obszarów Wiejskich. W ramach tego programu realizowane są cele zebrane w czterech osiach wiodących. Oś trzecia zajmuje się jakością życia na obszarach wiejskich i zajmuje się realizacją programu „Różnicowanie w kierunku działalności nierolniczej” (Rkdn PROW).

Kryteriami określającymi dostęp do programów jest ściśle określone grono odbiorców oraz miejsce ich zamieszkania. Mają to być rolnicy lub domownicy, w rozumieniu przepisów o ubezpieczeniu społecznym rolników, mieszkający na terenie gminy wiejskiej lub wiejsko-miejskiej, z wyłączeniem miejscowości liczących powyżej 5 tys. mieszkańców (SPO 2005, PROW 2010).

Wsparcie oferowane w ramach tych projektów dotyczy działań mających na celu uruchomienie lub rozwój działalności dodatkowej w zakresie: agroturystyki, usług związanych z turystyką i wypoczynkiem, usług na rzecz rolnictwa i gospodarki leśnej, prowadzenia na małą skalę przetwórstwa produktów rolnych lub jadalnych produktów leśnych, sprzedaży bezpośredniej produktów pochodzących w większości z własnego gospodarstwa rolnego (w PROW 2007-2013 wprowadzono dodatkowo sprzedaż detaliczną i hurtową), wytwarzania materiałów energetycznych z biomasy, rzemiosła i rękodzielnictwa oraz usług dla ludności (SPO 2005, PROW 2010).

Pomoc finansowa udzielana jest $\mathrm{w}$ formie refundacji części poniesionych kosztów, uznawanych za koszty kwalifikowalne. Maksymalna wysokość pomocy finansowej udzielonej jednemu beneficjentowi i gospodarstwu rolnemu nie może przekroczyć 100 tys. zł w okresie realizacji programu. Koszty kwalifikowalne mogą obejmować budowę, rozbudowę, remont budynków, zakup instalacji technicznej, maszyn i urządzeń, wyposażenia i sprzętu, zagospodarowanie terenu czy zakup środków transportu (SPO 2005, PROW 2010).

\section{Wysokość środków przyznanych dla poszczególnych lat i województw oraz stopień ich wykorzystania}

Podział środków pomiędzy województwa dla działania Rdr SPO i Rkdn PROW dokonywany był na postawie wskaźnika liczebności grupy docelowej gospodarstw, który został skonstruowany w oparciu o wielkość ekonomiczną gospodarstw wyrażoną ESU - Europejską Jednostką Wielkości (Goraj 2005) oraz liczbę ludności zamieszkującej obszary wiejskie w poszczególnych województwach. Na podstawie tego wskaźnika dokonano podziału środków na tzw. koperty regionalne (Uchwata $n r 3 / 2004$ ). 
W ramach SPO 2004-2006 dla działania „Różnicowanie działalności rolniczej i zbliżonej do rolnictwa w celu zapewnienia różnorodności działań lub alternatywnych źródeł dochodu” przeznaczono kwotę 312686385,00 zł. Łącznie złożono 7170 wniosków na łączną kwotę 524 782 386,36 zł, a więc na 167,8\% dostępnego limitu finansowego. Po weryfikacji formalnej pozostało 6205 wniosków. Ostatecznie podpisano 4106 umów na kwotę 296797 484,81 zł, przy czym płatności zostały zrealizowane na kwotę 282028 241,46 zł dla 4015 wniosków. Jest to $53,4 \%$ sumy przyznanej dla całego programu.

Zainteresowanie działaniem dla poszczególnych województw, jak i wykorzystanie koperty regionalnej, było zróżnicowane. W ramach Rdr SPO najmniej wniosków wpłynęło w lubuskim, zachodniopomorskim i opolskim, a najwięcej w lubelskim, mazowieckim oraz małopolskim (ryc. 1).

Ryc. 1. Liczba wniosków złożonych w ramach działania Rdr SPO

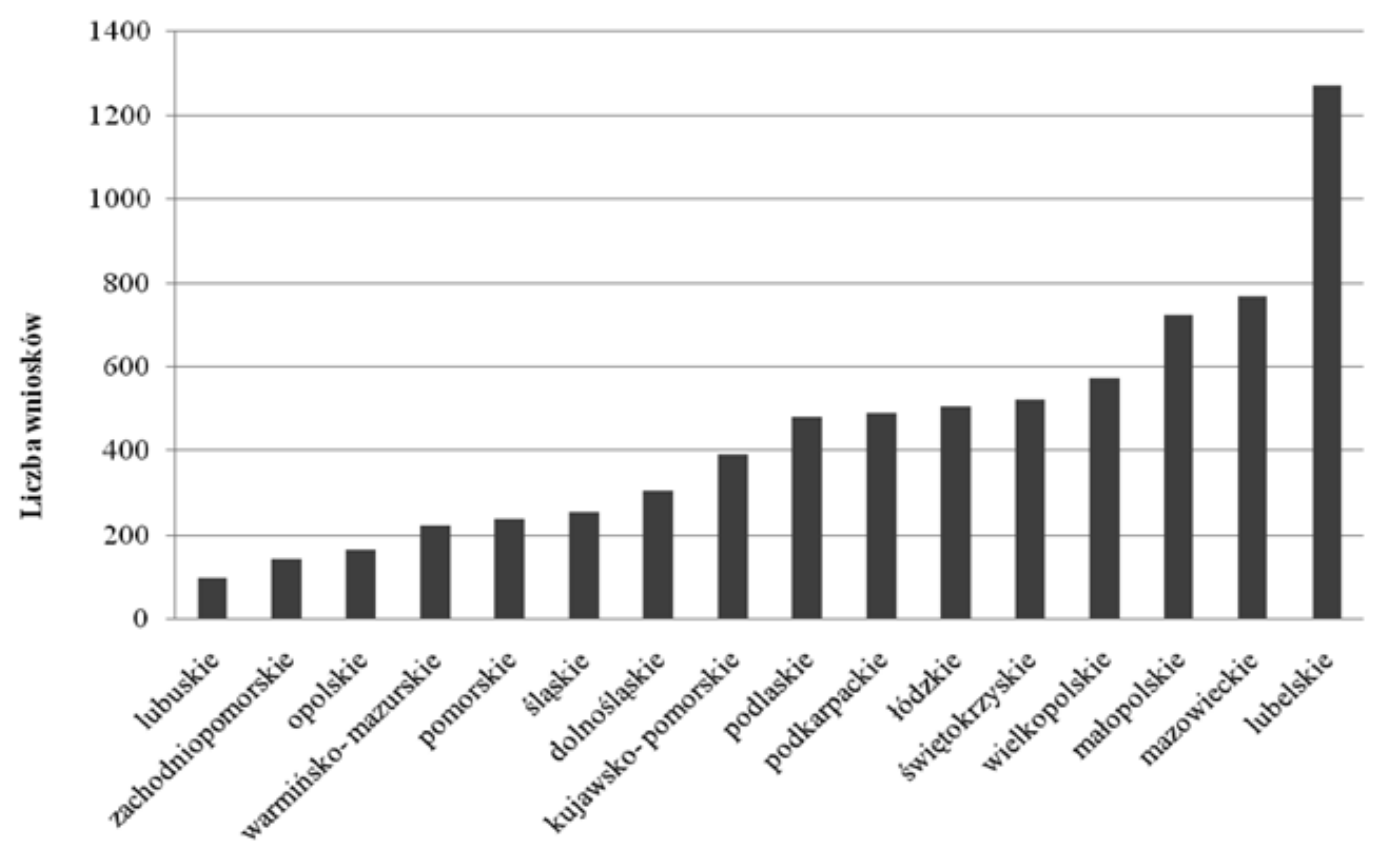

Źródło: opracowanie własne na podstawie danych Systemu Informacji Zarządczej ARiMR.

Innym ważnym elementem obrazującym jakościowe zagospodarowanie środków przeznaczonych do ww. programu jest stopień wykorzystania kwoty, którą beneficjent zadeklarował we wniosku o finansowanie działalności. Porównanie wartości kwoty planowanej do wykorzystania przy finansowaniu inwestycji oraz kwoty przyznanej wykazuje, że najlepiej wykorzystano środki w województwach: świętokrzyskim, lubelskim i małopolskim (powyżej 60\%), najsłabiej - w dolnośląskim, lubuskim oraz zachodniopomorskim (32-39\%). Uwzględniając cały obszar Polski, można zauważyć, że prawie połowa środków zadeklarowanych we wnioskach o przyznanie pomocy nie została wypłacona. 
Ryc. 2. Porównanie wartości kwot wnioskowanych z wartością kwot przyznanych w ramach działania Rdr SPO 2004-2006 z podziałem na województwa

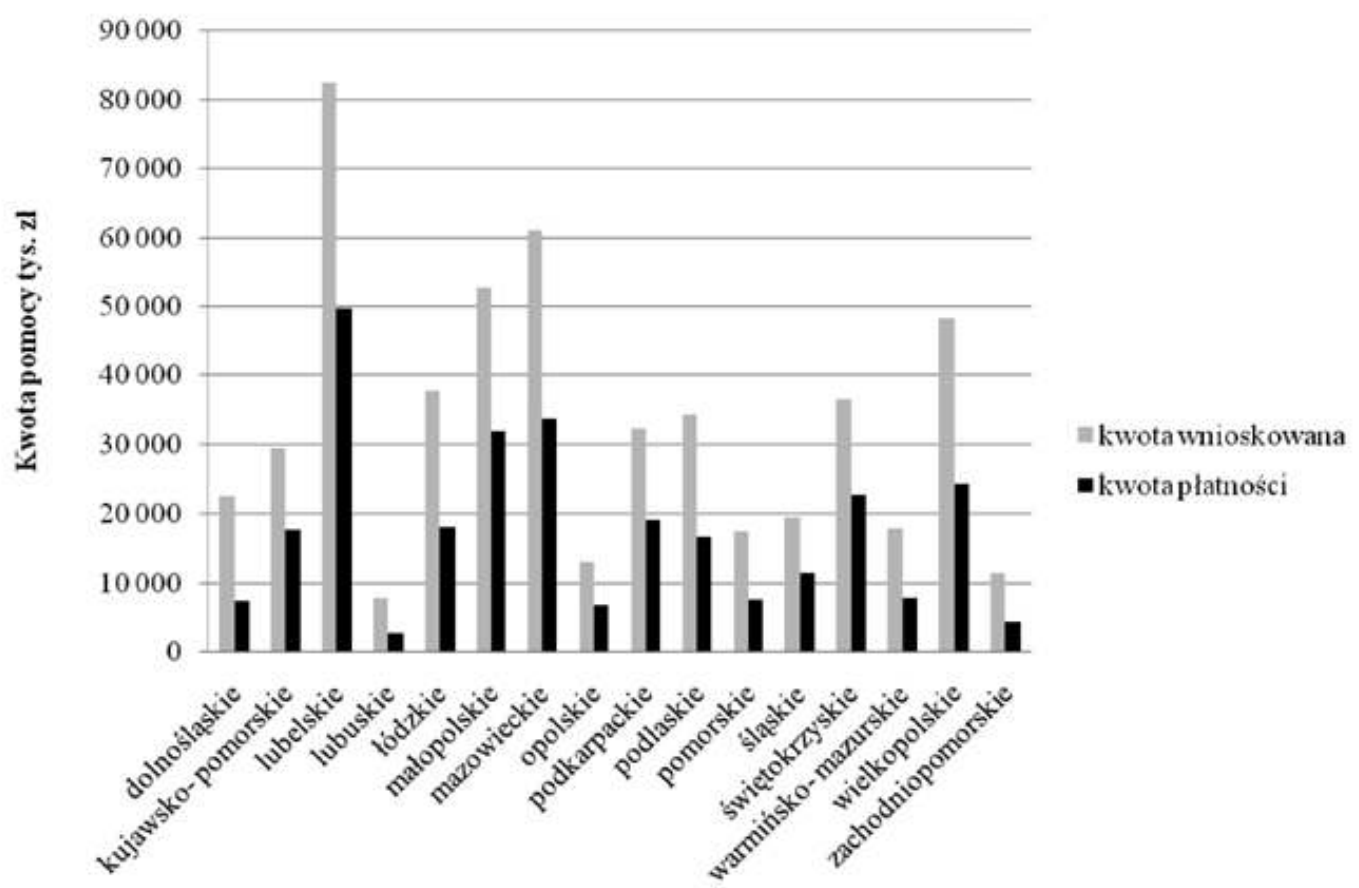

Źródło: opracowanie własne na podstawie danych Systemu Informacji Zarządczej ARiMR.

Jak już wcześniej wspomniano - w ramach programu Rdr SPO beneficjent mógł się starać maksymalnie o 100 tys. zł dofinansowania. Średnia kwota wnioskowanej pomocy w ramach edycji w programie SPO 2004-2006 wynosiła 73191 zł. Najniższe wartości inwestycji były w województwie zachodniopomorskim, opolskim, kujawsko-pomorskim (do 70 tys. zł), najwyższe w małopolskim (pow. 84 tys. zł).

Po zakończeniu wdrażania Sektorowego Programu Operacyjnego rozpoczęto wprowadzanie działania „Różnicowanie w kierunku działalności nierolniczej w ramach PROW 2007-2013”. Rkdn PROW zawiera podobne założenia programowe - ponownie beneficjenci mają możliwość uzyskania do 100 tys. zł pomocy. Ważnym czynnikiem wpływającym na stopień zainteresowania Rkdn PROW jest fakt, iż program ten ma bardzo zbliżone kryteria dostępu, jak znany już beneficjentom Rdr SPO. Dzięki nagłośnieniu w środkach masowego przekazu program trafia do szerokiej rzeszy odbiorców - jest dobrze rozreklamowany.

W ramach PROW 2007-2013 dla działania „Różnicowanie w kierunku działalności nierolniczej” nabór wniosków prowadzony był w 2008, 2009 i 2010 r. (nabór niezakończony). Kryteria podziału puli środków na poszczególne województwa były podobne jak w przypadku działania Rdr SPO.

Porównując nabory wniosków z lat 2008, 2009 i 2010, zauważa się wyraźną zmianę w liczbie złożonych wniosków dla poszczególnych województw. W każdej edycji najwięcej wniosków złożono w województwie mazowieckim i wielkopolskim. Odnośnie najmniejszej liczby złożonych wniosków zróżnicowanie jest większe. W 2008 r. najmniej było ich w lubuskim i opolskim, w 2009 r. - w lubuskim i zachodniopomorskim, a w 2010 - podkarpackim i śląskim. Należy zwrócić uwagę na to, iż w województwach małopolskim i lubelskim liczba złożonych wniosków jest znacznie niższa w stosunku do Rdr SPO. Nabór Rdr SPO wyróżniał się bowiem dużym zainteresowaniem w kierunku tworzenia działalności agroturystycznej. W ciągu kolejnych lat to zainteresowanie zmalało, natomiast inne działalności (w tym głównie usługi dla rolnictwa, które stanowiły ponad połowę wszystkich wniosków w kraju) nie miały tak dużych możliwości rozwoju, jak np. w województwie wielkopolskim. 
Ryc. 3. Liczba wniosków złożonych w trzech edycjach Rkdn PROW z podziałem na województwa

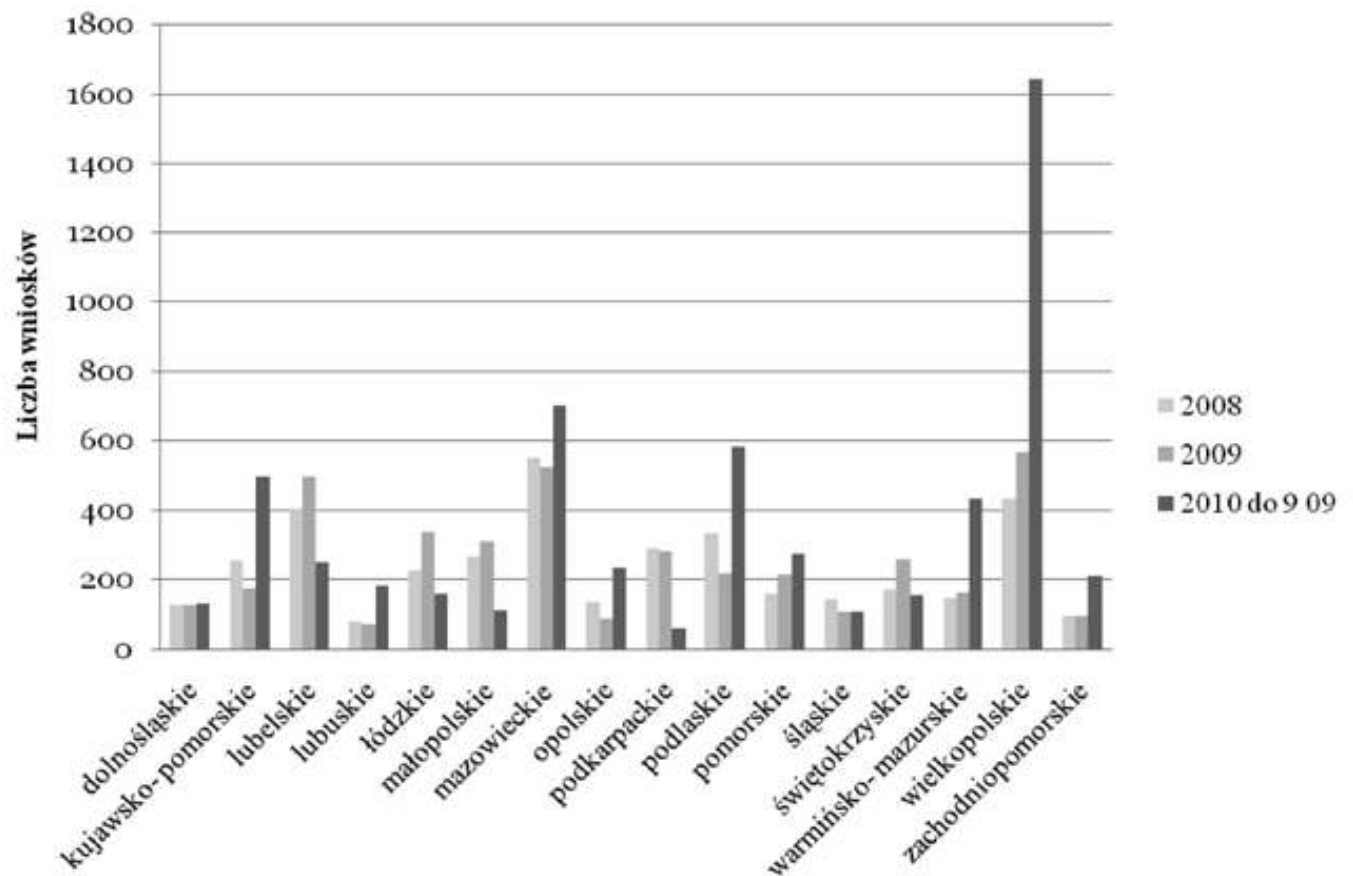

Źródło: opracowanie własne na podstawie danych Systemu Informacji Zarządczej ARiMR.

Stopień wykorzystania środków na terenie całej Polski mierzony liczbą zawartych umów w stosunku do liczby złożonych wniosków wzrósł z 52\% w 2008 r. do 58\% w 2009 r. Wskazuje to na bardziej przemyślane decyzje w kwestii realizowanych inwestycji. Warto podkreślić, że wartość z 2009 r. może być wyższa, gdyż część wniosków może być jeszcze w trakcie realizacji. Porównując lata 2008 i 2009, większość województw odnotowuje wzrost stopnia wykorzystania deklarowanych środków, niektóre regiony osiągnęły wartość 70\% w 2009 r.; są to: śląskie, opolskie, warmińsko-mazurskie i lubelskie. Tylko cztery województwa zanotowały spadek udziału wniosków o płatność w ogólnej liczbie złożonych wniosków w roku 2009.

Ryc. 4. Procentowy udział umów zawartych z ARiMR w ogólnej liczbie wniosków złożonych w Oddziałach Regionalnych ARiMR (edycja w 2008 i 2009 r.)

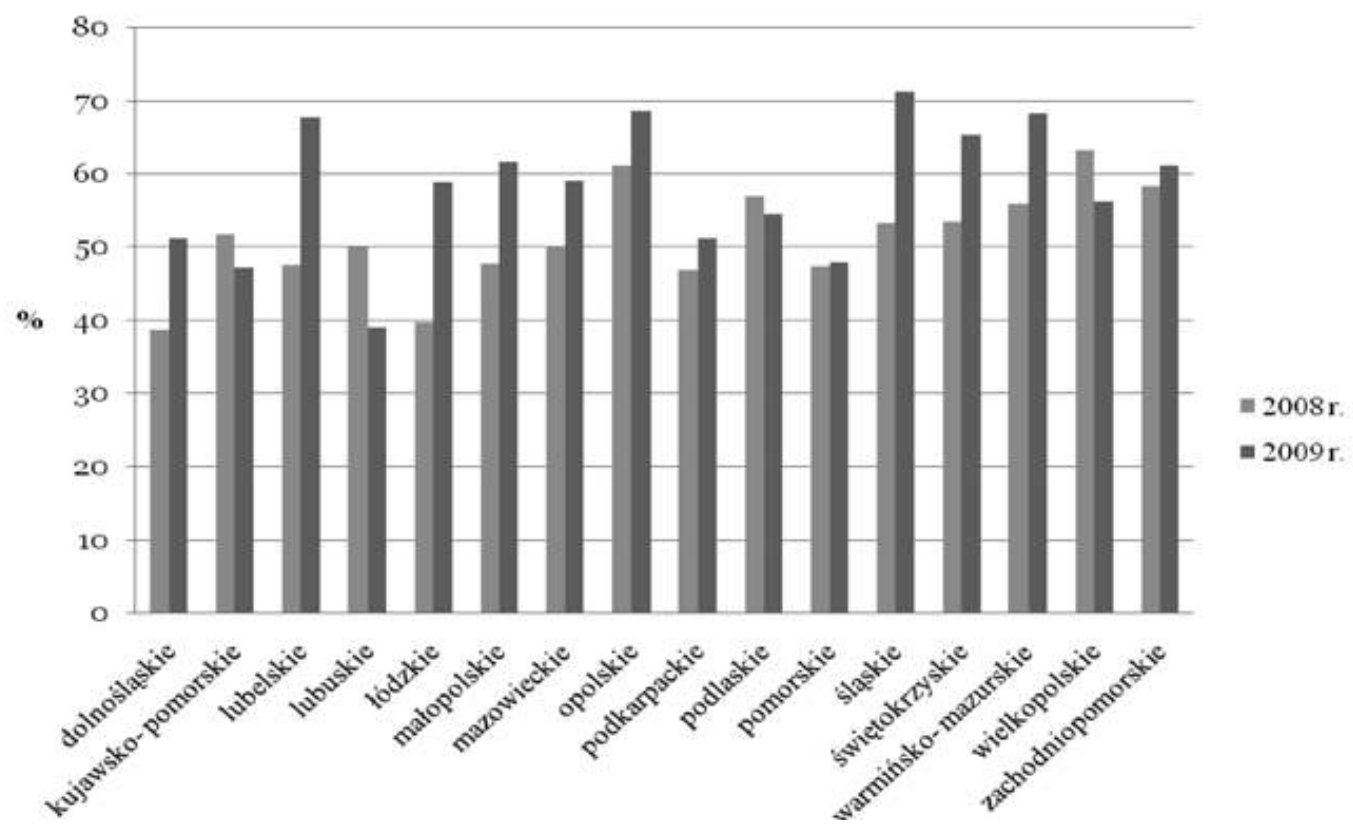

Źródło: opracowanie własne na podstawie danych Systemu Informacji Zarządczej ARiMR. 
Analizując wartość średniej kwoty wnioskowanej pomocy, zauważa się znaczny wzrost wartości dla działania Rkdn PROW 2007-2013 w stosunku do SPO 2004-2006. W 2008 r. wynosiła ona 81810 zł, w 2009 - 80099 zł, natomiast w 2010 r. było to już 92969 zł. W każdej $\mathrm{z}$ edycji najmniejsze średnie wartości osiągały inwestycje $\mathrm{w}$ podkarpackim, opolskim, małopolskim, a najwyższe w wielkopolskim, zachodniopomorskim, mazowieckim i lubuskim.

Ryc. 5. Średnia wartość kwoty wnioskowanej pomocy dla czterech edycji przyjmowania wniosków w ramach działań Rdr SPO oraz Rkdn PROW

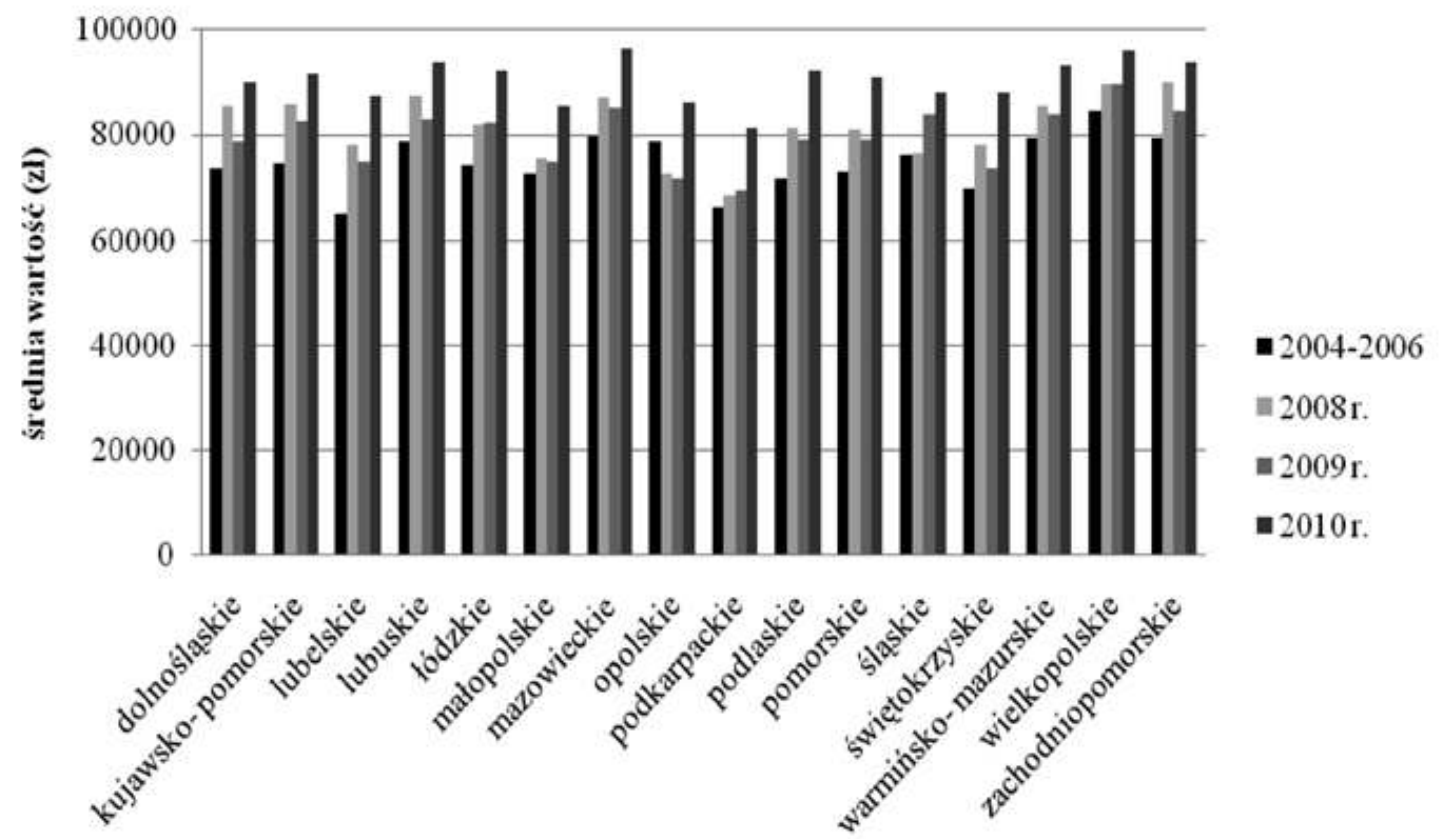

Źródło: opracowanie własne na podstawie danych Systemu Informacji Zarządczej ARiMR.

Kolejnym elementem wskazującym na zainteresowanie mieszkańców wsi programem „Różnicowanie w kierunku działalności nierolniczej” jest zróżnicowanie czasowe wykorzystania puli środków dla poszczególnych województw. W myśl terminarza realizacji programów Agencja Restrukturyzacji i Modernizacji Rolnictwa powiadamiała o planowanym uruchomieniu naboru wniosków dla poszczególnych działań w ramach najpierw SPO, a obecnie PROW. Następnie Oddziały Regionalne ARiMR-u prowadziły monitoring kwoty pomocy zadeklarowanej w składanych wnioskach i w chwili przekroczenia o $20 \%$ puli przeznaczonej dla danego województwa oddział ogłaszał kolejny dzień roboczy ostatnim do przyjmowania wniosków. W tabeli 1 przedstawiono daty, gdzie najwcześniej zakończono przyjmowanie wniosków dla działania Rdr SPO oraz Rknd PROW.

W SPO program uruchomiono 15 września 2004 r., a nabór trwał do 14 kwietnia 2006 r. W części województw większe zainteresowanie spowodowało, że zakończenie przyjmowania wniosków nastąpiło już w 2005 r. Taka sytuacja miała miejsce w pomorskim, lubuskim i warmińsko-mazurskim. Jeszcze szybsze tempo wykorzystania środków zaobserwowano w ramach Rdr PROW 2007-2013. Potencjalni beneficjenci byli znacznie lepiej zorientowani w zasadach pozyskiwania środków. Należy też nadmienić, że w ramach tego programu czas przyjmowania wniosków w każdej z edycji mógł trwać nie dłużej niż do 31 grudnia danego roku. Od dnia 5 czerwca 2008 r. rozpoczęto przyjmowanie wniosków i w tym dniu limit 120\% został wyczerpany w województwach: kujawsko-pomorskim, lubuskim, podlaskim, pomorskim, warmińsko-mazurskim, wielkopolskim i zachodniopomorskim. Dnia 11 czerwca wstrzymano program w dolnośląskim, 16 czerwca w mazowieckim i opolskim, a 25 czerwca - w śląskim. 
Dnia 15 kwietnia 2009 r. został uruchomiony drugi nabór w ramach PROW 2007-2013. Wyczerpanie limitu skutkowało wstrzymaniem naboru najpierw w wielkopolskim, pomorskim i zachodniopomorskim, a potem kolejno w: warmińsko-mazurskim, lubuskim i kujawsko-pomorskim. W pozostałych województwach limit nie został wyczerpany, a zakończenie przyjmowania wniosków nastąpiło 31 grudnia 2009 r. W dniu 24 sierpnia 2010 r. ruszyła kolejna edycja programu. W tym dniu limit złożonych wniosków został przekroczony w województwach: warmińsko-mazurskim, wielkopolskim, zachodniopomorskim, lubuskim i kujawsko-pomorskim. Ponadto do końca sierpnia wstrzymano jeszcze nabór w pomorskim, opolskim i podlaskim. W pozostałych województwach przyjmowanie wniosków nie jest zakończone, a stopień wyczerpania limitu jest bardzo niewielki, np. w małopolskim na dzień 9 września 2010 r. było to $16 \%$.

Tab. 1. Wybrane daty zakończenia przyjmowania wniosków w poszczególnych latach i województwach

\begin{tabular}{|c|c|c|c|c|}
\hline $\begin{array}{c}\text { Data rozpoczęcia } \\
\text { przyjmowania wniosków }\end{array}$ & $\begin{array}{l}15 \text { września } \\
2004\end{array}$ & $\begin{array}{l}5 \text { czerwca } \\
2008\end{array}$ & $\begin{array}{l}15 \text { kwietnia } \\
2009\end{array}$ & $\begin{array}{l}24 \text { sierpnia } \\
2010\end{array}$ \\
\hline Rok edycji & \multirow{2}{*}{2005} & \multirow{2}{*}{2008} & \multirow{2}{*}{2009} & \multirow{2}{*}{2010} \\
\hline Województwo & & & & \\
\hline dolnośląskie & * & 11 czerwca & * & * \\
\hline kujawsko-pomorskie & $*$ & 6 czerwca & 31 sierpnia & 25 sierpnia \\
\hline lubelskie & * & * & * & $*$ \\
\hline lubuskie & 3 czerwca & 6 czerwca & 16 czerwca & 25 sierpnia \\
\hline łódzkie & $*$ & * & * & * \\
\hline małopolskie & 10 listopada & $*$ & $*$ & * \\
\hline mazowieckie & * & 16 czerwca & * & * \\
\hline opolskie & $*$ & 16 czerwca & * & 30 sierpnia \\
\hline podkarpackie & 31 sierpnia & * & * & * \\
\hline podlaskie & $*$ & 6 czerwca & $*$ & 31 sierpnia \\
\hline pomorskie & 9 marca & 6 czerwca & 22 maja & 27 sierpnia \\
\hline śląskie & 18 listopada & 25 czerwca & * & * \\
\hline świętokrzyskie & * & * & * & * \\
\hline warmińsko-mazurskie & 15 czerwca & 6 czerwca & 12 czerwca & 25 sierpnia \\
\hline wielkopolskie & 20 lipca & 6 czerwca & 19 maja & 25 sierpnia \\
\hline zachodniopomorskie & 31 sierpnia & 6 czerwca & 28 maja & 25 sierpnia \\
\hline
\end{tabular}

* zakończenie naboru w 2006 r. dla Rdn SPO, zakończenie naboru w kolejnych miesiącach lub 31 grudnia danego roku - Rkdn PROW.

Źródło: opracowanie własne na podstawie danych Departamentu Komunikacji Społecznej ARiMR. 
Wsparcie rozwoju obszarów wiejskich jest ważnym elementem przyczyniającym się do poprawy jakości życia na tych terenach. Programy wspierające rozwój działalności pozarolniczych mogą być dodatkowym bodźcem dla rodzin z terenów wiejskich do poszukiwania pozarolniczych źródeł dochodu. Przeprowadzona analiza pozyskiwania środków z programu Rdr w SPO, i PROW wskazuje na duże zróżnicowanie przestrzenne zarówno co do liczby składanych wniosków, jak i tempa wykorzystania środków dla poszczególnych województw. Zauważa się słabe wykorzystanie środków w ramach Rdr PROW w województwach o dużym udziale gospodarstw o niskiej dochodowości (małopolskie, podkarpackie, śląskie). Natomiast szybkie zagospodarowanie przyznanej pomocy w województwach warmińsko-mazurskim, wielkopolskim i zachodniopomorskim może być ważnym czynnikiem do zmiany kryteriów podziału środków na regiony. Wzrost zainteresowania programem Rdr w województwach o dużym udziale gospodarstw wysokotowarowych może wskazywać na inwestowanie w maszyny rolnicze, które służą zarówno do produkcji we własnym gospodarstwie, jak i dają możliwość podjęcia dodatkowej działalności w zakresie usług dla rolnictwa. Kolejne edycje wskazują, że beneficjenci planują finansowanie coraz droższych inwestycji, natomiast wciąż zbyt niskie jest wykorzystanie deklarowanych środków. Nadal prawie połowa planowanych we wnioskach inwestycji nie jest realizowana. Może to wynikać ze zbyt długiego okresu rozpatrywania wniosków, a także z braku wkładu własnego na rozpoczęcie inwestycji.

\section{Literatura}

1. Babuchowska K., 2009, Działalność nierolnicza na obszarach wiejskich w województwie warmińsko-mazurskim finansowana w ramach PROW 2007-2013, Roczniki Naukowe Stowarzyszenia Ekonomistów Rolnictwa i Agrobiznesu, tom XI, zeszyt 5, Poznań.

2. Bański J., 2004, Możliwości rozwoju alternatywnych źródet dochodu [w:] Pozarolnicza działalność gospodarcza na obszarach wiejskich, Studia Obszarów Wiejskich, tom 5, red. E. Pałka, Warszawa.

3. Błąd M., 2006, Dywersyfikacja ekonomiczna wsi [w:] Polska wieś. Raport o stanie wsi 2006, J. Wilkin, I. Nurzyńska (red.), FDPA, Warszawa.

4. Fałkowski J., 2005, Sektorowy Program Operacyjny „Restrukturyzacja i modernizacja sektora żywnościowego oraz rozwój obszarów wiejskich”. Próba oceny dotychczasowych efektów, „Analizy i Opinie", Nr 54, Kraków.

5. Goraj L., 2005, Wptyw płatności bezpośrednich na dochody polskich gospodarstw rolnych, Urząd Komitetu Integracji Europejskiej, Warszawa.

6. Komitet Sterujący Sektorowym Programem Operacyjnym, Uchwała nr 3/2004.

7. Program Rozwoju Obszarów Wiejskich, 2010, Działanie 311, Poradnik dla beneficjentów, Agencja Restrukturyzacji i Modernizacji Rolnictwa, Warszawa.

8. Sektorowy Program Operacyjny, 2005, Poradnik dla beneficjentów, Działanie 2.4, Agencja Restrukturyzacji i Modernizacji Rolnictwa, Warszawa. 


\section{Assessment of the Use of Funds under the Programme „Różnicowanie w kierunku dzialalności nierolniczej” [Diversification into non-agricultural activities]}

The paper analyzes the use of EU funds for farmers wishing to start or expand a business. The study was based on the use of funds under the program "Diversification into non-agricultural activities" located within the Sectoral Operational Programme for the years 2004-2006 (SOP) and the Rural Development Plan 2007-2013 (RDP). The assessment indicated a wide variation in the use of the program in different voivodehips. These differences appear when comparing the activities associated with the SOP and those implemented under the RDP. The first edition was popular in the voivodehips characterized by a high percentage of low income households. Implementation of the RDP program has brought a significant change in the number of applications and in the speed of the utilization of resources in regions. The greatest interest in the program in the three editions of the RDP occurred in the voivodehips (with the high agriculture level) where large farms dominate the agricultural and the means are used for service activity. It may be an indicator for changes in the specifications on allocation of resources. The lack of interest in the voivodehips with a large number of not profitable farms and with an excess labour force is puzzling. Subsequent editions indicate that investments planned by the beneficiaries are becoming more thoughtful and the investment value is increasing. 